J. Product. \& Dev., 18(2):129 - 136 (2013)

\title{
EFFECT OF SOME PESTICIDES AGAINST Tetranychus cucurbitacearum (SAYED) UNDER LABORATORY CONDITIONS
}

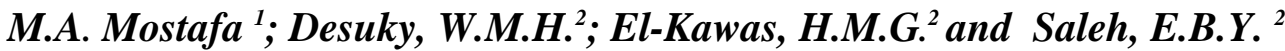
1- Agric. Zoology and Nematology Dept., Fac. of Agric., Al-Azhar Univ., Cairo, Egypt.

2- Plant Protection Research Institute, A.R.C., Dokki, Egypt.

\section{ABSTRACT}

Laboratory studies were carried out to evaluate the toxicity effects of four compounds i.e. fenpyroximate and chlorfenapyr as acaricides, chlorpyrifos as organophosphorus and lambdacyhalothrin as pyrethroid were investigated against adult females of the two-spotted spider mite, Tetranychus cucurbitacearum (Sayed) (Acari: Tetranychidae) under laboratory conditions. Concerning the $L C_{50}$ values, the tested compounds could be arranged descending as follow: chlorfenapyr, fenpyroximate, chlorpyrifos, and lambdacyhalothrin recorded 0.32, 0.79, 28.69 and 432.19 ppm., respectively. Data revealed that chlorfenapyr and fenpyroximate shorten the oviposition period, female longevity, and reduced number of laid eggs compared to control.

Conclusively, the present study reported that chlorphenapyr was the potent toxicity compound against adult females of $T$. cucurbitaceraum followed descending by fenpyroximate, chlorpyrifos, and lambda-cyhalothrin according to $L C_{50}$ of the tested compounds. In addition to chlorfenapyr shorted the oviposition period, female longevity, and reduced number of laid eggs compared to fenpyroximate.

Key words: Tetranychus cucurbitacearum, fenpyroximate, chlorfenapyr, chlorpyrifos, lambda-cyhalothrin.

\section{INTRODUCTION}

Field crops, vegetables and fruit trees are infested by sucking pests as aphids, white flies and mites (Dahroug et al., 2000). Phytophagous mites especially members of the family Tetranychidae are responsible for significant yield losses for many host plants. The tetranychid mites including the two-spotted spider mites, $T$. urticae and $T$. cucurbitacearum has been recognized as an important sucking pests of more than 900 host plants and is described as a serious pest of at least 150 economically 
important agricultural and ornamental plants (Zaher, 1984 ; El-Enany et al., 2001and Zhang, 2003). These pests causing highly damage to its host plants in the world. Leaves injury resulting from tetranychid mites infestation was mainly due to the sucking of cell sap, resulting in yellow, brown botch and accompanied by dry and leaf fall resulting in the loss of fruit quality and quantity of the production (Huffaker et al., 1969; Hell \& Sabelis, 1985; ElHalawany et al., 1986; Pande et al., 1996 and El-Kawas, 2000).

Many studies were interested in evaluate the different compounds to control or reducing damage of phytophagous mites for their host plants (Davis, 1952; Henneberry et al., 1960 and Ghaderi et al., 2012).

So, the present study aimed to evaluate the efficiency of four pesticides namely; chlorfenapyr, fenpyroximate, chlorpyrifos and lambdacyhalothrin against $T$. cucurbitacearum females. Also, the effect of $\mathrm{LC}_{50}$ of chlorfenapyr and fenpyroximate on some biological aspects of $T$. cucurbitacearum were studied.

\section{MATERIALS AND METHODS}

\section{1- Rearing technique:}

Samples of eggplant leaves, Solanum melongena L. heavily infested with $T$. cucurbitacearum were collected from Zagazig district, Sharkia Governorate. Pure culture of T. urticae was initiated and transferring male and females using a fine hair brush to fresh discs of mulberry leaves, Morus alba L. in Petri-dishes $(10 \mathrm{~cm}$. in diameter). Each leaf was put on a pad of cotton wool saturated with water as a source of moisture, and to prevent mite escaping, under laboratory conditions $27 \pm 2{ }^{\circ} \mathrm{C}$ and $65 \pm 5 \%$ R.H (ElKawas et al., 2008).

\section{2- Tested pesticides:}

1- Fenpyroximate (Ortus super ${ }^{\circledR}$ 5\% EC), 1,1-dimethylethyl (E)-4[[[[(1,3-dimethyl- 5-phenoxy-1H-pyrazol-4-yl)methylene] amino] oxy]methyl]benzoate, used at the rate of $50 \mathrm{~cm}^{3} / 100$ liter of water, a trademark of Nihon Nohyaku.

2- Chlorfenapyr (Challenger ${ }^{\circledR} 24 \%$ EC), 4-bromo-2-(4-chlorophenyl)-1(ethoxymethyl)-5- (trifluoromethyl)-1H-pyrrole-3-carbonitrile, used at rate of $60 \mathrm{~cm}^{3} / 100$ liters of water, a trademark of BASF.

3- Chlorpyrifos (Dursban ${ }^{\circledR} 48 \%$ ), O,O-diethyl O-(3,5,6-trichloro-2pyridinyl) phosphorothioate, used at rate of 1liter of feddan a trademark of Dow Agro science.

4- Lambda-cyhalothrin (Lamda $\mathrm{ZD}^{\circledR} 5 \%$ EC), O-(4-bromo-2-chlorophenyl) O-ethyl S-propyl phosphorothioate, $\left[1 \square\left(\mathrm{S}^{*}\right), \quad 3 \square(\mathrm{Z})\right]-( \pm)$-cyano(3-phenoxyphenyl)methyl 
3-(2-chloro-3,3,3-trifluoro-1-propenyl) -2,2-dimethylcyclopropanecar-boxylate, used at $375 \mathrm{~cm}^{3}$ / feddan of water, a trademark of Syngenta Agro Egypt.

3. Toxicity action against $T$. cucurbitacearum adult females:

The toxicity of chlorfenapyr, fenpyroximate, chlorpyrifos and lambda-cyhalothrin were evaluated against adult females of $T$. cucurbitacearum. Ten adult females of the same age were transferred to a leaf disc of mulberry ( 1 inch in diameter) and sprayed with different concentrations for each compound, fenpyroximate $(0.1,1,5$, and $10 \mathrm{ppm}$.), chlorfenapyr $(0.05,0.1,0.5$ and $1 \mathrm{ppm}$.), chlorpyrifos (200, 500, 750, and $1000 \mathrm{ppm}$.) and lambda-cyhalothrin (10, 20, 50, and $80 \mathrm{ppm}$.) using a glass atomizer. These discs were placed on their lower surface on pads of moist cotton wool in Petri-dishes. Six replicates for each treatment were used. Untreated discs were sprayed with water only as a control. The mortality percentages were calculated after $72 \mathrm{hr}$. after spray according to Abbott's equation (1925). Toxicity Index calculated according to Sun equation (1950).

\section{Latent effects of Fenpyroximate and Fenpyroximate on $T$. cucurbitacearum females:}

Six gravid females of $T$. cucurbitacearum were transferred to mulberry leaf discs $\left(3 \mathrm{~cm}\right.$. in diameter) and sprayed with the $\mathrm{LC}_{50}$ of Fenpyroximate and Chlorfenapyr using a glass atomizer, while control was sprayed with water only. These discs were placed on their lower surface on pad of moist cotton wool in Petri-dishes. Ten replicates for both treatments were used. The adult female longevity (pre-oviposition, oviposition and post-oviposition), fecundity and deterrent index were recorded.

Deterrent index based on the number of laying eggs treatment compared to control was calculated according to the equation of Lundegren (1975):

$\mathrm{A}-\mathrm{B} / \mathrm{A}+\mathrm{B} \times 100$

$\mathrm{A}=$ number of eggs in control.

$\mathrm{B}=$ number of eggs in treated part.

The data were subjected to statistical analysis by Duncan's (1955) multiple range tests were used to determine the significant of the difference between mean values of the treatments.

\section{RESULTS AND DISCUSSION}

\section{1- Toxicity action against $T$. cucurbitacearum adult females:}

Data in Table (1) indicated that fenpyroximate was the highest effective against $T$. cucurbitacearum females, while chlorpyrifos was the lowest one. Based on $\mathrm{LC}_{50}$ and $\mathrm{LC}_{90}$ for the tested compounds can be arranged in the following descending order: chlorfenapyr, fenpyroximate, 
lambda-cyhalothrin and chlorpyrifos were (0.32 and 3.90), (0.79 and 228.91), (28.69 and 155.96) and (432.19 and 1713.88 ppm.), respectively.

At $\mathrm{LC}_{50}$ and $\mathrm{LC}_{90}$ the toxicity index of fenpyroximate, lambdacyhalothrin and chlorpyrifos were $40.70 \& 1.70 \%, 1.13 \& 2.5 \%$ and 0.075 $\& 0.22 \%$ against T. cucurbitacearum as compared with chlorfenapyr after $72 \mathrm{hr}$, of treatments.

Despite, chlorpyrifos insecticide and acaricide, data show that chlorpyrifos lower toxicity against $T$. cucurbitacearum may be due to acts as a contact poison, with some action as astomic poison.

The finding results are in agreement with Abdel-Samad (2002) revealed that lambda-cyhalothrin (Kendo $5 \%$ EC) recorded $85 \%$ mortality for $T$. urticae female observed at $24 \mathrm{hr}$. post application under laboratory conditions.

Table (1): Toxicity of some pesticides against $T$. cucurbitacearum females.

\begin{tabular}{|c|c|c|c|c|c|c|c|}
\hline \multirow[t]{2}{*}{ Treatments } & \multirow{2}{*}{$\begin{array}{l}\text { Con. } \\
\text { (ppm.) }\end{array}$} & \multirow{2}{*}{ 突 } & \multirow{2}{*}{$\begin{array}{l}\mathbf{L C}_{50} \text { ppm. } \\
\text { (Upper-Lower) }\end{array}$} & \multirow{2}{*}{$\begin{array}{c}\text { LC } \text { Co }_{90} \text { ppm. } \\
\text { (Upper- } \\
\text { Lower) }\end{array}$} & \multirow[t]{2}{*}{ Slope } & \multicolumn{2}{|c|}{$\begin{array}{l}\text { Toxicity } \\
\text { index at: }\end{array}$} \\
\hline & & & & & & $\mathbf{L C}_{50}$ & $\mathrm{LC}_{90}$ \\
\hline \multirow{4}{*}{ Chlorfenapyr } & 0.05 & 18.33 & \multirow{4}{*}{$\begin{array}{c}0.323 \\
(0.43-0.250)\end{array}$} & \multirow{4}{*}{$\begin{array}{c}3.908 \\
(8.945-2.257)\end{array}$} & \multirow{4}{*}{1.184} & \multirow{4}{*}{100} & \multirow{4}{*}{100} \\
\hline & 0.1 & 38.33 & & & & & \\
\hline & 0.5 & 58.33 & & & & & \\
\hline & 1.0 & 93.33 & & & & & \\
\hline \multirow{4}{*}{ Fenpyroximate } & 0.1 & 33.33 & \multirow{4}{*}{$\begin{array}{c}0.796 \\
(1.395-0.395)\end{array}$} & \multirow{4}{*}{$\begin{array}{c}228.926 \\
(2722.6-61.12)\end{array}$} & \multirow{4}{*}{0.521} & \multirow{4}{*}{40.704} & \multirow{4}{*}{1.70} \\
\hline & 1 & 50.00 & & & & & \\
\hline & 5 & 63.33 & & & & & \\
\hline & 10 & 75.00 & & & & & \\
\hline \multirow{4}{*}{$\begin{array}{l}\text { lambda- } \\
\text { cyhalothrin }\end{array}$} & 10 & 20.00 & \multirow{4}{*}{$\begin{array}{c}28.695 \\
(34.21-23.95)\end{array}$} & \multirow{4}{*}{$\begin{array}{c}155.974 \\
(259.87-111.13)\end{array}$} & \multirow{4}{*}{1.743} & \multirow{4}{*}{1.129} & \multirow{4}{*}{2.50} \\
\hline & 20 & 41.67 & & & & & \\
\hline & 50 & 65.00 & & & & & \\
\hline & 80 & 78.33 & & & & & \\
\hline \multirow{4}{*}{ Chlorpyrifos } & 200 & 25.00 & \multirow{4}{*}{$\begin{array}{c}432.152 \\
(497.6-366.6)\end{array}$} & \multirow{4}{*}{$\begin{array}{c}1713.328 \\
(2569.71-1318.7)\end{array}$} & \multirow{4}{*}{2.142} & \multirow{4}{*}{0.075} & \multirow{4}{*}{0.22} \\
\hline & 500 & 53.33 & & & & & \\
\hline & 750 & 66.67 & & & & & \\
\hline & 1000 & 81.67 & & & & & \\
\hline
\end{tabular}

2- Effect of $\mathrm{LC}_{50}$ for chlorfenapyr and fenpyroximate against $T$. cucurbitacearum females:

Obtained data in Table (2) showed that, fenpyroximate and chlorfenapyr shortened the longevity and reduced the fecundity of $T$. cucurbitacearum females. The pre-oviposition period recorded 1.72 and 1.96 days for fenpyroximate and chlorfenapyr, compared to 1.58 days for the control, respectively. On the other hand, the oviposition 
period lasted 8.68 and 12.22 days for the same order while was 16.05 days for control.

Table (2): Effect of $\mathrm{LC}_{50}$ for Challanger and Fenpyroximate against $T$. cucurbitacearum adult females:

\begin{tabular}{|c|c|c|c|c|c|c|}
\hline \multirow[b]{2}{*}{ Treatments } & \multicolumn{4}{|c|}{ Duration in days: } & \multirow[b]{2}{*}{ Fecundity } & \multirow{2}{*}{$\begin{array}{c}\text { Deterrent } \\
\text { index } \\
\%\end{array}$} \\
\hline & $\begin{array}{c}\text { Pre- } \\
\text { ovipostion }\end{array}$ & Ovipostion & $\begin{array}{c}\text { Post- } \\
\text { ovipostion }\end{array}$ & $\begin{array}{c}\text { Female } \\
\text { longevity }\end{array}$ & & \\
\hline Fenpyroximate & 1.72 & 8.68 & 1.63 & $11.71 \mathrm{c}$ & $18.72 \mathrm{c}$ & 54.85 \\
\hline Chlorfenapyr & 1.96 & 12.22 & 2.51 & $16.69 b$ & $24.51 b$ & 44.74 \\
\hline Control & 1.58 & 16.05 & 2.41 & $20.04 a$ & $64.20 \mathrm{a}$ & 00.00 \\
\hline
\end{tabular}

Means under each variety having different letters in the same column indicate a significant different $(\mathrm{P} \leq 0.05)$.

The adult female longevity lasted 11.71 and 16.69 days compared to 20.04 days for control. The total laid eggs number was 18.72 and 24.51 for fenpyroximate and chlorfenapyr compared to 64.20 eggs for control.

Fenpyroximate was more efficacy pesticides that reduced total laid eggs with deterrent index $54.85 \%$ followed by fenpyroximate $44.74 \%$. The results showed that effect of $\mathrm{LC}_{50}$ concentrations of fenpyroximate and chlorfenapyr significantly affected the fecundity and longevity of the treated females of $T$. cucurbitacearum. This results are agreement with Amjad et al. (2012) who revealed that chlorfenapyr caused the highest mortality percentages for $T$. urticae female $(100 \%)$ compared to fenpyroximate $(77 \%)$ under laboratory conditions.

Conclusively, the present study reported that chlorphenapyr was the potent toxicity compound against adult females of $T$. cucurbitaceraum followed descending by fenpyroximate, chlorpyrifos, and lambdacyhalothrin according to $\mathrm{LC}_{50}$ of the tested compounds. In addition to chlorfenapyr shorted the oviposition period, female longevity, and reduced number of laid eggs compared to fenpyroximate.

\section{REFERENCES}

Abbott, W. S. (1925): A method of computing the effectiveness of an insecticide. J. Econ. Entomol., 18 (2): 265-267.

Abdel-Samad, M.A. (2002): Side effects of some pesticides on Tetranychus urticae Koch (Acarina: Tetranychidae) and their 
predatory mites, Euseius scutalis (A.H.) and Phytoseiulus persimilis A.-H. (Acarina: Phytoseiidae). Egypt. J. Apple. Sci., 17(3): 342-360.

Amjad, M.; Bashir, M. H.; Gogi, M. D.; Muhammad, A.; Khuram, Z.; Khan, M. A. and Ali, L. (2012): Evaluation of some acaricides against two spotted spider mites, Tetranychus urticae Koch (Acari: Tetranychidae) on cotton crop under laboratory and field conditions. Pakistan Entomologist, 34(2): 125-129.

Dahroug, S.M.; Sobeiha, A.K.; Farragg, A.M.J. and Bakr, E.M. (2000): Repellency effect of certain botanicale extracts against the red spider mite and black bean aphid. Annals of Agric. Sc., Moshtohor, 38(4): 2543-2550.

Davis, D. W. (1952): some effects of DDT on spider mites J. Entomol., 45, 1011-1019.

Duncan, D. B. (1955): Multiple ranges and multiple F. test. Biometrics, 11: $1-41$.

El-Enany, M.A.; Abdel-Rahman, S.I. and Ibrahim, A.I. (2001): Evaluation of certain acaricides on Tetranychus cucurbitacearum (Sayed) and T. urticae Koch and predaceous insects and mites associated with cotton plants in lower and upper Egypt. Egypt. J. Appli., Sci, 16(10): 259-268.

El-Halawany, M.E.; Kandeel, M.M.H. and Rakha, M.A. (1986): Mites inhabiting deciduous fruit trees in Egypt. Agric. Res. Rev., 4(1): 115122.

El-Kawas, H.M.G. (2000): Ecological and biological studies on some mites associated with orchards and field crops. M. Sc. Thesis, Fac. of Agric., Al-Azhar Univ.: 154 pp.

El-Kawas, H.M.G; Mead, H. M. I. and Desuky, W.M.H. (2008): Repellency and toxic effect of certain compounds against Tetranychus urticae Koch (Acari: Tetranychidae). Egypt. J. of Agric. Res., 86(1): 331-339.

Ghaderi, S.; Minaee, K.; Akrami, M.; Aleosfour, M. (2012): The effect of fenpyroximate on life table parameters of Tetranychus urticae under laboratory conditions. Iranian J. of Plant Protec. Science, 43(2): 251-260.

Helle, W. and Sabelis, M. W. (1985): Spider mites: their biology, natural enemies and control. Vol. 1B, Elsevier, Amsterdam, Holland.

Henneberry, T. J.; Taylor, E. A.; Smith, F. F. and Boswell, A. L. (1960): Comparative acaricidal activity of strains of the two- spotted spider mite. J. Econ. Entomol., 53: 841-843. 
Huffaker, C.B.; van de Vrie, M. and McMurty, J.A. (1969): The ecology of tetranychid mites and their natural control. Ann. Rev . Entomol. $14: 125-174$.

Lundegren, L. (1975): Natural plant chemical acting as oviposition deterrent on cabbage butterflies Pieris brassicae (L.), P. rapae (L.) and P. napi (L.). Zool. Sci., 4: 253-258.

Pande, Y.D.; Ray, D.C. and Saha, H.P. (1996): Seasonal incidence of Tetranychus cinnabarinus (Boisd.) (Acarina: Tetranychidae) and loss yield in okra crop. J. Adv. Zool., 17: 7-14.

Sun, Y. P. (1950): Toxicity index - An improved method of comparing the relative toxicity of insecticides. J. Econ. Entomol., 43 (1): 45-53.

Zaher, M. A. (1984): Survey and ecological studies on phytophagous, predaceous and soil mites in Egypt.1. phytophagous mites in Egypt (Nile Valley and Delta), PL. 480 programme U.S.A. project no. EGARS-30 Grant No. FG.EG. 139, 228 pp.

Zhang, Z.-Q. (2003): Mites of Greenhouses: Identification, biology and control. CABI Publishing, Wallingford, 244 pp. 


\section{تأثير بعض المبيدات على الحلم العنكبوتي ذو البقعتين تحت الظروف المعملية}

مصطفي عبد اللطيف مصطفي' ــوحيد محمود حسين دسوقي ‘ـ هانى محمد جلال الدين القواص׳ - المعتز بالله يوسف صالح`

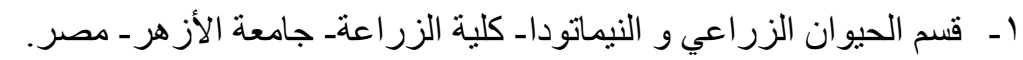

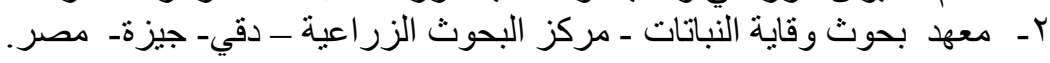

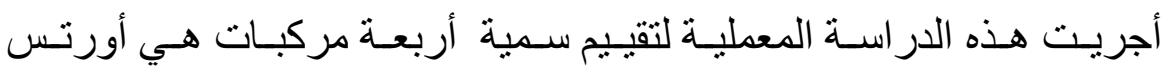

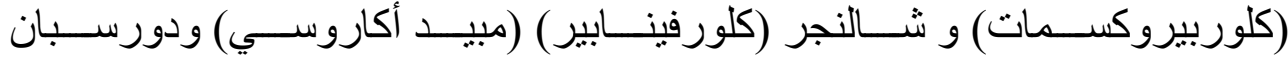

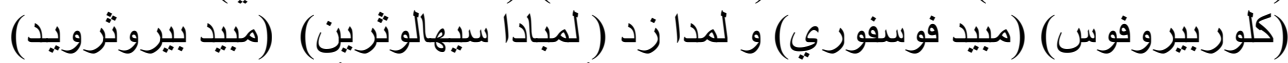

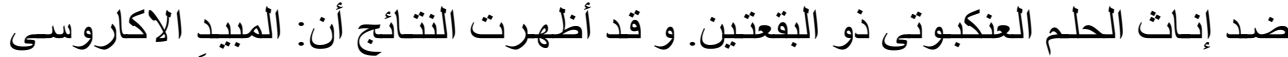

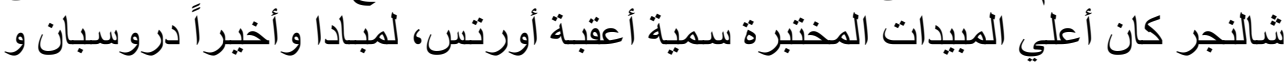

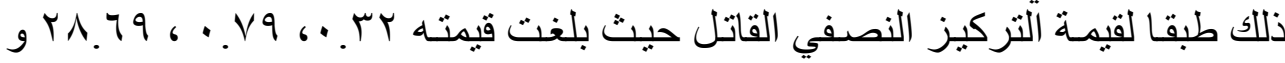

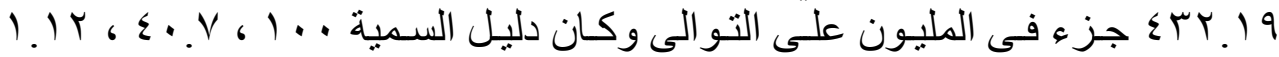

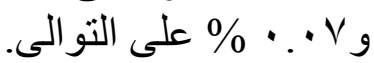

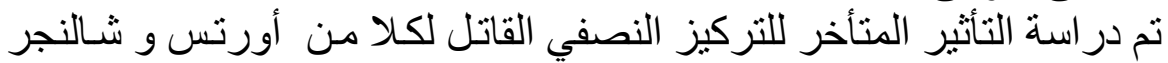

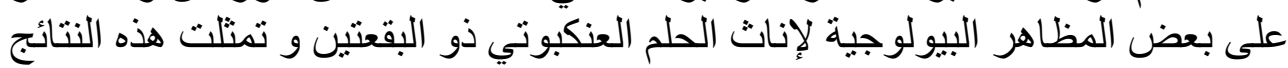

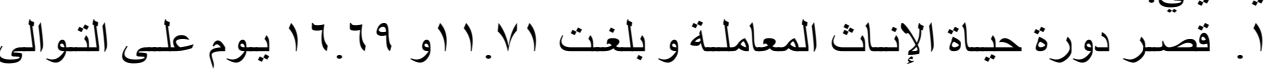

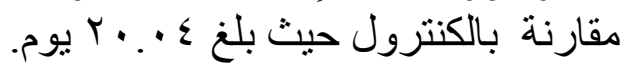

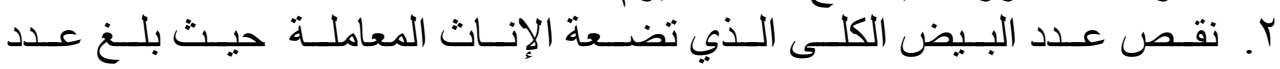

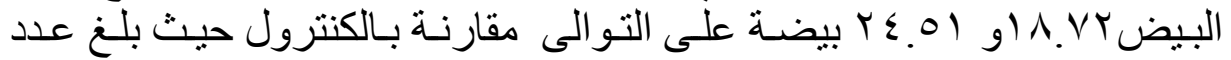
البيض Y ـ ₹7 بيضة.

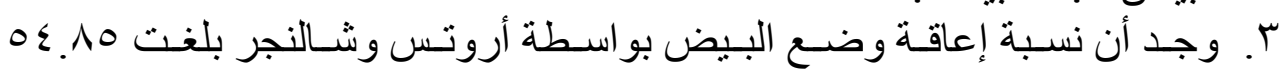

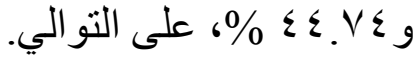
التوصية: 